IZA DP No. 7852

Business Cycles, Unemployment and Entrepreneurial Entry: Evidence from Germany

Michael Fritsch Alexander Kritikos Katharina Pijnenburg

December 2013 


\title{
Business Cycles, Unemployment and Entrepreneurial Entry: Evidence from Germany
}

\author{
Michael Fritsch \\ Friedrich Schiller University Jena \\ and DIW Berlin \\ Alexander Kritikos \\ DIW Berlin, University of Potsdam, \\ $I Z A$ and $I A B$
}

Katharina Pijnenburg

DIW Berlin

Discussion Paper No. 7852

December 2013

\author{
IZA \\ P.O. Box 7240 \\ 53072 Bonn \\ Germany \\ Phone: +49-228-3894-0 \\ Fax: +49-228-3894-180 \\ E-mail: iza@iza.org
}

\begin{abstract}
Any opinions expressed here are those of the author(s) and not those of IZA. Research published in this series may include views on policy, but the institute itself takes no institutional policy positions. The IZA research network is committed to the IZA Guiding Principles of Research Integrity.

The Institute for the Study of Labor (IZA) in Bonn is a local and virtual international research center and a place of communication between science, politics and business. IZA is an independent nonprofit organization supported by Deutsche Post Foundation. The center is associated with the University of Bonn and offers a stimulating research environment through its international network, workshops and conferences, data service, project support, research visits and doctoral program. IZA engages in (i) original and internationally competitive research in all fields of labor economics, (ii) development of policy concepts, and (iii) dissemination of research results and concepts to the interested public.
\end{abstract}

IZA Discussion Papers often represent preliminary work and are circulated to encourage discussion. Citation of such a paper should account for its provisional character. A revised version may be available directly from the author. 
IZA Discussion Paper No. 7852

December 2013

\section{ABSTRACT}

\section{Business Cycles, Unemployment and Entrepreneurial Entry: Evidence from Germany}

We investigate whether people are more willing to become self-employed during boom periods or during recessions and to what extent business cycles or unemployment levels influence entries into entrepreneurship. Our analysis for Germany reveals that there is a positive relationship between unemployment rates and start-up activities. Moreover, new business formation is higher during recessions than in boom periods. This implies that new business formation is counter-cyclical. When disentangling periods of low and high unemployment we find that the effect of unemployment on new business formation is only statistically significant if the level of unemployment is below the trend, indicating a "low unemployment retain effect".

JEL Classification: L26, E32

Keywords: $\quad$ self-employment, business cycle, unemployment, start-up

Corresponding author:

Alexander Kritikos

DIW Berlin

Mohrenstr. 58

10117 Berlin

Germany

E-mail: akritikos@diw.de

\footnotetext{
* We are indebted to Adam Lederer, Dieter Nautz, Roy Thurik, and an anonymous referee for helpful comments as well as to Alina Sorgner and Michael Wyrwich for preparing the data on new business formation. All authors declare to have observed the IZA Guiding Principles of Research Integrity.
} 


\section{Introduction}

There is an ongoing discussion whether business cycles influence rates of entry into entrepreneurship. ${ }^{1}$ Do people become self-employed more often during boom periods or during recessions? Is it high or low unemployment rates that exert an impact on entrepreneurial entries? Does new business formation reflect a pro-cyclical effect or is it countercyclical?

While there are good reasons to expect that individual decisions for or against self-employment are shaped by business cycle fluctuations, competing effects may occur. For instance, nascent entrepreneurs may positively react to an upswing by setting up new ventures because of a friendly business climate that leads them to expect higher returns on investments. Accordingly, they may show a low propensity to start up in a downturn. A second line of argument claims that transition rates into self-employment may increase when employment opportunities are rare, and start start-up rates may be low when employed positions are more easily available.

Beyond the question of how to interpret the venturing of a business at certain points of a cycle, it is clear that if entries into entrepreneurship prevail during upswings they unfold pro-cyclical effects while higher entries into self-employment during recessions would point to a countercyclical effect. ${ }^{2}$ Both types of reasons could but must not relate to different types of new businesses and might have consequences for the further development of the economy. As it is indistinct from a theoretical point of view which of the different effects on new business formation will prevail, an empirical analysis is required.

\footnotetext{
${ }^{1}$ Recent contributions include Congregado, Golpe and Parker (2012), Koellinger and Thurik (2012) and Parker, Congregado and Golpe (2012). See also Blanchflower (2000) for an earlier approach.

${ }^{2}$ This implies the assumption that there are no longer time lags between the decision to start an own business and putting this decision into practice.
} 
This contribution analyzes the effect of macro-level factors on transition rates into self-employment for Germany. We combine data on new business formation - the gross inflow into self-employment - as measure for entrepreneurship with the relevant macro-economic variables for a 15 year period. Our analysis is, to the best of our knowledge, the first of its kind for Germany. By focusing on the relationship between GDP growth, unemployment, interest-rates and transitions into self-employment over the business cycle, this paper investigates whether macro-economic conditions influence entry rates into entrepreneurship. As we investigate the effect on gross entry this analysis differs from most previous work in this field, which usually uses net entry as dependent variable.

Our analysis shows that between 1996 and 2010 unemployment rates in Germany positively influenced entry rates into self-employment. We also reveal that the cyclical component of real GDP has a rather negative effect on entrepreneurial entry rates. Interestingly, when we further disentangle periods of relatively low and relatively high unemployment, we find an asymmetric relationship that points to a "low unemployment retain effect." This means that the relationship between unemployment and the level of new business formation is only statistically significant when unemployment levels are below the trend.

The remainder of the paper is organized as follows. In Section 2 we present our research questions in greater detail and discuss how the development of GDP and unemployment may influence entrepreneurial entry. In this section, we also debate why gross entry should be preferred to net entry in this kind of analysis. We then describe in Section 3 the datasets used for our analysis. Section 4 is devoted to the econometric approach and the presentation of the results including robustness checks. Section 5 relates our findings to previous approaches and discusses the limitations, Section 6 concludes. 


\section{Why the business cycle is related to new business formation}

\subsection{Theoretical considerations}

Empirical research shows that nascent entrepreneurs may start their own businesses for very different motivations. ${ }^{3}$ Reasons influencing decisions at the individual level could, among others, be the macroeconomic environment like the general business climate, the level of unemployment, or the number of job opportunities. From the overall economic perspective it becomes then also important to understand to what extent these macroeconomic factors do influence entry rates into entrepreneurship. More specifically, it is crucial to know from a policy perspective whether entry rates vary pro- or counter-cyclically.

There are basically three macroeconomic forces that may influence entry rates into entrepreneurship. Starting with the GDP, it is plausible to expect that start-up rates may increase during GDP growth periods because of a positive environment for investments, such as growing demand and widespread optimism about the future development. In line with this reasoning, fewer individuals may then be willing to enter selfemployment during recession periods when future developments appear relatively uncertain and investments are perceived as risky (Rampini, 2004). In a similar vein, Barlevy (2007) argues that entrepreneurs may tend to introduce radical innovations during growth periods, thereby causing acceleration effects as such innovations that eventually lead to further innovative activities and entrepreneurial opportunities could induce strong increases in GDP. ${ }^{4}$ These claims are

\footnotetext{
${ }^{3}$ There are an increasing number of studies analyzing factors that influence the transition into entrepreneurship at a micro-level. These approaches reveal that demographic (see e.g. Levesque and Minniti, 2006), educational (Block, Hoogerheide and Thurik, 2012), economic (see e.g. Blanchflower and Oswald, 1998), and personality characteristics (see e.g. Caliendo, Fossen and Kritikos, 2009, 2010, 2012, 2013) affect the decision to start an own business.

${ }^{4}$ Further arguments in the same direction were earlier suggested by Shleifer (1986).
} 
often associated with the "opportunity pull" argument and should lead to pro-cyclical effects of economic growth on entrepreneurial activities.

However, GDP development may also unfold differing forces. Caballero and Hammour (1994) argue that entrepreneurs will enter markets when they are better able to exploit new technologies and displace incumbents, and that such exploitation takes place during recessions. Also Francois and Lloyd-Ellis (2003) argue that entrepreneurs enter markets with innovative products when labor and production costs are low, i.e. during recessions or when unemployment is high. They will in particular enter during such times when they are able to store their innovations and sell them later when demand is high during the next boom period. Thus, with respect to GDP there might be different forces at work which may unfold either pro- or countercyclical effects, very much depending on which effect prevails.

The second macro-economic factor potentially unfolding dynamics on entrepreneurial entries is the level of unemployment and of alternative employment opportunities. Following occupational choice models (see e.g., Davidsson, 2004; Parker, 2009), people may switch from employment or unemployment into self-employment if starting an own business appears to be more rewarding than the status-quo. If the levels of unemployment benefits are low or short termed, the occupational choice approach suggests that transitions into selfemployment may occur more often during periods when the level of unemployment is relatively high. Accordingly, the level of start-ups may be relatively low in periods when more employment opportunities are available and the level of unemployment is relatively low. The influence of the unemployment level on entrepreneurial entries is connected with the "recession-push" argument and should lead to counter-cyclical effects of unemployment levels.

Interestingly, Roman, Congregado and Millán (2013) further elaborate on this argument as they combine the effects of unemployment levels with GDP development. They hypothesize that 
there might be different effects of high unemployment on the quality of entries even if these are coming out of unemployment, with entrepreneurial entries being more opportunity (necessity) driven during boom (recession) periods. This argument would then again weaken the counter-cyclical effect.

A third factor that may unfold effects on new business formation is the development of interest rates. Low interest rates in recessions lower the cost of capital and may stimulate the investment in new businesses while high interest rates in boom periods may prevent some potential founders from setting up their own firm in particular when they need substantial amounts of capital for their venture (see e.g. Parker, 2009).

From a theoretical perspective, there are several macro-economic forces operating in different directions. If the effects during good economic times prevail, entries into self-employment could have a destabilizing effect on the economy. ${ }^{5}$ If unemployment combined with low interest rates during recessions indeed stimulates entries into selfemployment and if relatively rich employment opportunities and high interest rates in boom periods lead to low levels of start-ups, this may be regarded as a counter-cyclical effect, thus stabilizing the economy.

The types of entrepreneurs that are attracted by these two effects could be quite different. If entry rates are more dominated by opportunity entrepreneurs that seek to realize a certain idea, their impact on economic development would be more positive than if new businesses are more dominated by necessity entrepreneurs. Although the motivation for running an own business may change over time, it is

\footnotetext{
${ }^{5}$ Although there are a number of reasons to assume that the business cycle affects the level of new business formation, there may also be a causal relationship in the opposite direction, i.e. that start-ups have also an effect on the business cycle. While an effect of demand or unemployment on the level of new business formation may occur with a considerable time lag, one may also expect that new business formation is a leading time series if start-ups influence the business cycle. Koellinger and Thurik (2012) found first evidence for such an effect. We restrict our analysis, however, on effects of the business cycle on new business formation.
} 
a widespread expectation that firms set up out of need are smaller, with fewer employees, and affect growth less than firms founded for opportunity reasons (see e.g. Hessels et al., 2008). However, as our theoretical considerations clarify, there is no deterministic relationship between specific points of the business cycle and the quality of entrepreneurial entries.

\subsection{Previous empirical research}

The net outcome of these contradicting effects of demand, unemployment and interest rates on the level of new business formation is an empirical question. The available empirical evidence about the relationship between new business formation and the business cycle is, however, still rather inconclusive. As to the relationship between GDP growth and entrepreneurship, studies from the 1990s suggests a procyclical influence of periods of growth and recessions on the number of entrepreneurial entries (see e.g. Grant, 1996, for the US, Carrasco, 1999, for Spain). Interestingly, studies for more recent years show no such cyclicality.

The empirical findings for the relationship between unemployment and entrepreneurship are also rather mixed. Parker (2009) reports, that 1990s era investigations with cross sectional data find a non-significant or a significant negative relationship between the level of unemployment and entry rates into entrepreneurship. Conversely, investigations using data from the 2000s find a positive effect. Research based on time-series data arrived at mixed results. Robson (1998) finds no evidence for a recession push effect for Great Britain while Georgellis and Wall (2000) reveal a positive relationship between entrepreneurial entry and a rising level of unemployment for the regions of Great Britain (more or less in the same time period of the 1980s and early 90s). Further results pointing to a recession push effect are reported for Finland by Tervo (2006) and Tervo and Niittykangas (1994), and for Italy by Foti and Vivarelli (1994). The latter observation is in line with Blanchflower (2000), who analyzes this relationship for 
OECD countries and finds a positive link only for two countries, Italy and Iceland, while the relationship between the levels of unemployment and entrepreneurship is negative for all other OECD countries.

A possible reason for the different findings dependent on the timeperiod of the analysis could be changes in individual attitudes toward entrepreneurship. This interpretation is in line with the hypothesis of Audretsch and Thurik (2000) (see also Thurik, Stam and Audretsch, 2013) who argue for a shift from a managerial to an entrepreneurial society. Another reason could be that the more recent research allowed for more controls and applied better methods of analysis (see Parker, 2009). A third reason is the data quality and the way how entries into entrepreneurship are measured. Summarizing the existing empirical evidence still leaves us with the puzzle whether any of the possible macroeconomic effects prevail?

\subsection{Research questions and measurement of entrepreneurship}

This paper explores what kind of macro-economic effects influence entrepreneurial entry rates in Germany. More specifically, we examine in which direction (a) high or low unemployment rates, (b) boom or recession periods in the business cycle measured by GDP development, and (c) changes in interest rates may influence entry rates into entrepreneurship. We further investigate to what extent it is the cyclical component of these macro-economic variables that might influence entry rates, and to what extent influences of variables are symmetric. Our investigation should reveal whether pro- or countercyclical effects unfold a stronger influence on entrepreneurial entries.

We are not aware of any recent analysis of the relationship between new business formation and the business cycle for Germany. ${ }^{6}$

\footnotetext{
${ }^{6}$ The most recent known analysis is by Blanchflower (2000), who studies all OECD countries, including Germany, with data ending in 1996. The analysis of Román, Congregado and Millán (2013), which focuses on start-ups out of unemployment, is based on the 1994-2001 European Household Panel. It also includes about 50
} 
While most of the investigations that are available for a small number of other countries use changes of the stock of entrepreneurs as dependent variable (net-entry), our analysis is based on transitions into self-employment (gross-entry). We believe that gross entry is far better suited for identifying the effects of macro-variables on entrepreneurship for three reasons.

- First, as the number of entries and exits quite often are of about equal size, changes in the stock of self-employment largely conceal changes in the gross flows. Because gross entries show greater variation over time than the respective net-changes in the stock of existing businesses, we expect to identify the relationship in a more direct way than it would be the case for net-entry.

- Second, the macroeconomic factors that influence exits out of selfemployment may be quite different from the determinants of entry (see e.g. Caballero and Hammour, 1994). Analyzing net-entry may, thus, confound these two groups of determinants such that the factors that drive entry and exit cannot be clearly distinguished from one another. ${ }^{7}$

- Third, analyzing the gross influx of business founders into selfemployment may provide better information about the dynamics of the economy. In this context it is often argued that increased entrepreneurial activities in the sense of more new businesses may considerably stimulate economic performance (van Stel, Carree and Thurik, 2005); either because entrepreneurs enter markets with new products or production processes (see Acs and Audretsch, 2003),

individuals entering self-employment in Germany, and does (because of the small number of observations) not present any specific results for the country.

${ }^{7}$ Obviously, using net-entry as indicator for new business formation risks mismeasurement as the following examples show. If we assume exits from selfemployment to be stable over time, then the net-entry would be a perfect substitute for full entry. The same dynamics in net-entries could, however, occur if the number of entries is constant and only the number of exits changes over the business cycle. 
because they create new jobs, or because they contribute to increased productivity by contesting established market positions (see Nickell, 1996). Since there are few indications of important positive effects of business closures on growth, an analysis of gross entry appears to be particularly interesting.

Therefore, overall we argue that information on gross entry is a superior measure for the relationship between macroeconomic fluctuations and the decision to become self-employed.

\section{Data}

\subsection{Data on start-up activity, unemployment, and GDP}

In our analysis we use two different data sources that provide information about start-up activities in Germany, namely the Business Registration Statistics and the German Micro-Census. To capture the most relevant aspects of the business cycle in the analysis, we use real GDP growth and the cyclical component of real GDP, as well as the unemployment rate, the cyclical component of the unemployment rate, and interest rates.

Since data for start-up activities tend to have their peculiarities we describe the two data sources that we use in more detail. The Business Registration Statistics counts the notifications of new businesses recorded in the Business Register (Leiner, 2002), and are a complete inventory count. Every individual starting a legal business as selfemployed person, with the appearance of permanency and with the aim of realizing profits, is required to register the business with the municipal trade office. Since 1996 a harmonized recording of business registrations from across Germany is available on a monthly basis.

The main advantages of this source are the timely recording of the data, the monthly availability, and the fact that solo-entrepreneurs are also included, i.e. those who start with no employees. This data source has, however, several disadvantages, as well. First, while soloentrepreneurs are included in this source, it does not provide any 
further information on business characteristics. We do neither know whether the firm is run by the entrepreneur alone or whether further individuals are employed, nor in which sector the business is started. Second, there are a considerable number of cases where a notification is made but no business is founded, leading to an overestimation of entries (Brüderl, Preisendoerfer and Ziegler, 2009). Third, start-ups by freelancers and in the liberal trades are not covered as they are not required to register. ${ }^{8}$ In total, however, there is evidence that the number of start-ups is rather overestimated in this source (Fritsch, et al., 2002).

The second data source that we use is the German Micro-Census, ${ }^{9}$ an annual representative survey containing socio-economic information about approximately 820,000 individuals living in 380,000 households. ${ }^{10}$ Our analysis draws on 14 waves of the Micro-Census, starting with 1996, when the sample introduced a question for business founders. The classification of individuals as self-employed in the Micro-Census is based on a survey question about the employment status of the respondent. Self-employment as an employment status applies to those individuals who own a business, including self-employed craftsmen as well as freelancers and self-employed persons in the liberal trades. We identify business founders by using the responses to the question about when they have started their present employment or self-employment. ${ }^{11}$ Those who became self-employed in the time period between the last and the present survey are classified as business founders. Furthermore, it is also possible for the complete observation period to

\footnotetext{
${ }^{8}$ See Oberlander (2004). There are no statistics on start-ups by these groups.

${ }^{9}$ Data access was provided on-site at the Federal Statistical Office in Erfurt.

${ }^{10}$ The Micro-Census was started in 1957 as an annual survey of private households and persons in West Germany and was expanded to include East German states in 1991. The aim of this study is to collect nationally representative micro-data about the population structure, economic and social situation of individuals and households.

${ }^{11}$ The corresponding question in the Micro-Census was introduced in 1996.
} 
identify in which quarter of the year the start-up took place (for more details on this data source, see Statistisches Bundesamt, 2009).

The main advantage of this source is its high representativeness and the inclusion of solo-entrepreneurs. Unfortunately, however, the information is available only with a considerable time lag. A further limitation of the Micro-Census is that it does not contain sufficient numbers of observations for an analysis at regional levels below the level of Federal States, for an analysis differentiating between soloentrepreneurs and other entrepreneurs, or differentiating between industry sectors on a regional level making use of quarterly data. ${ }^{12}$ Moreover, the statistics do not capture those business founders who entered and exited self-employment between two waves (Fritsch, Kritikos and Rusakova, 2012). Despite these shortcomings, the MicroCensus can be regarded as an appropriate data source for the analysis of self-employment in Germany.

As a consequence of the differences between the two sources with regard to data gathering, they report quite different numbers of startups. Despite these differences in absolute number, they show, however, rather similar trends over time, particularly since 2003 (as we will show Section 3.2). We are, thus, able to use the two data sets for mutual robustness checks of our results when analyzing the influence of various macroeconomic variables on start-up activities in Germany.

The number of unemployed persons and unemployment rates are provided by the Federal Employment Agency (FEA, Bundesagentur für Arbeit). The FEA defines the unemployment rate as the share of registered unemployed over the working population, i.e. those who are employed or self-employed plus the registered unemployed. To capture a possible cyclical component in the time-series of the unemployment

\footnotetext{
${ }^{12}$ All numbers taken from the Micro-Census are extrapolated to the entire population in the respective spatial unit (Federal level or States) using the weights provided by the Federal Statistical Office.
} 
rate we apply the Hodrick-Prescott (HP) filter (Hodrick and Prescott, 1997). The unemployment rate for German Länder is available from 1994 to 2010 . Thus, the decomposition into trend and cyclical component is performed over a period of 17 years. The nominal Gross Domestic Product (GDP) on the level of the German Federal States is provided on a yearly basis by Volkswirtschaftliche Gesamtrechnung der Länder (Macroeconomic Accounting of the Federal States). Real GDP is calculated using the annual Consumer Price Index (CPI) of the Federal Statistical Office. In the estimation we use the growth rate of real GDP and the cyclical component of the HP-filtered real GDP. The availability of data on real GDP from 1991 to 2010 allows for the estimation of the trend and the cyclical component for a 20 year period.

We further include an annual measure of knowledge capital into our analysis, namely patent applications over civil employment, provided by the Federal Statistical Office. In this way we take into account that knowledge based factors are found to have an impact on start-up activities (De Clercq and Arenius, 2006). Furthermore, following Fritsch and Wyrwich (2014) we include the self-employment rate as a measure of entrepreneurship culture in our estimation. Thereby we account for the fact that new business formation is partly independent of current economic conditions. The annual self-employment rate is provided by Volkswirtschaftliche Gesamtrechnung der Länder. For data on interest rates we use the lending rate of banks for long-term fixed rate loans to enterprises and self-employed persons provided by the German Bundesbank until 2003. This series is then linked to the interest rates of German banks for loans to non-financial corporations, available from the German Bundesbank from 2003 on.

\subsection{Descriptives and correlation analysis of measured start-up activity}

We begin our empirical analysis with an overview of the observed startup activities, unemployment, and the development of GDP over the observation period. According to the Micro-Census, there were more 
than 1.5 million (about 300,000 per year) transitions into selfemployment (as a primary activity) between 1996 and 2000. After a decline in 2001, the number of business founders increased up to a peak of 361,000 in 2005 (Figure 1). During this period the support for start-ups out of unemployment was substantially expanded (see Caliendo und Kritikos, 2010). According to the Micro-Census the number of founders dropped to fewer than 300,000 in 2008 and 2009.

Figure 1: Annual number of business registrations reported by the Business Register and annual number of business formations reported in the Micro-Census

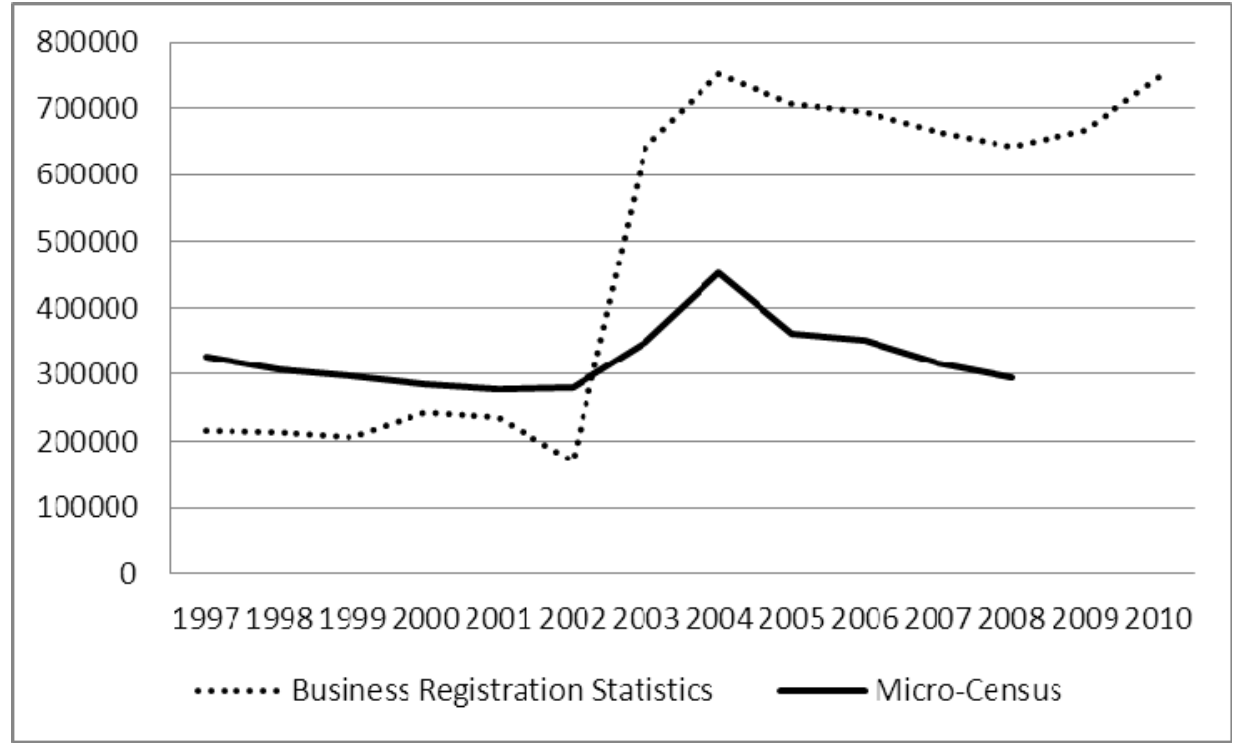

A similar trend is observed in the data from the Business Register, however, as already mentioned, partly at a much higher level. For 1997, the first year of the standardized business register, this source counts 215,000 registrations. In 2004, the number of start-ups, according to this data source, reached its peak with 750,000 registrations. It dropped to 640,000 registrations in 2008 , but then almost reached 750,000 again in 2010. The development of the number of business registrations suggests that the reform of the business registration statistic introduced in 2003 led to a large increase in the number of business registrations. 
Correlations between the information on the number of start-ups provided by the two data sets reveal that the correspondence over time was rather low before the reform (correlation coefficient: 0.04 ) and then considerable improved starting in the year 2003 (correlation coefficient: 0.88 ; Table 1). Since the Micro-Census contains only relatively few start-ups for the smaller Federal States, we aggregate the 16 Federal States to four larger regions (North, South, East, and West) in order to have reasonable numbers of observations. ${ }^{13}$

Table 1: Correlations between the macroeconomic variables

\begin{tabular}{|c|c|c|c|c|c|c|}
\hline $\begin{array}{l}\text { New businesses } \\
\text { (Micro-Census) } t=0\end{array}$ & $\begin{array}{c}\text { Business } \\
\text { registrations } \mathrm{t}=0 \\
\text { 1997-2008: } 0.69^{* * *} \\
\text { 1997-2002: } 0.04 \\
\text { 2003-2008: } 0.88^{* * *}\end{array}$ & $\begin{array}{c}\text { New businesses } \\
\text { (Micro-Census) } \\
t=0\end{array}$ & $\begin{array}{l}\text { Real GDP } \\
\text { growth } \\
\text { rate } \mathrm{t}=0\end{array}$ & $\begin{array}{l}\text { Real GDP } \\
\text { growth } \\
\text { rate t-1 }\end{array}$ & $\begin{array}{l}\text { Unem- } \\
\text { ployment } \\
\text { rate } t=0\end{array}$ & $\begin{array}{l}\text { Unem- } \\
\text { ployment } \\
\text { rate t-1 }\end{array}$ \\
\hline $\begin{array}{l}\text { Real GDP growth } \\
\mathrm{t}=0\end{array}$ & -0.07 & -0.10 & & & & \\
\hline $\begin{array}{l}\text { Real GDP growth } \\
\mathrm{t}-1\end{array}$ & -0.20 & $-0.70^{\star * *}$ & -0.20 & & & \\
\hline $\begin{array}{l}\text { Unemployment } \\
\text { rate } t=0\end{array}$ & -0.29 & 0.41 & 0.11 & 0.10 & & \\
\hline $\begin{array}{l}\text { Unemployment } \\
\text { rate t-1 }\end{array}$ & -0.26 & 0.28 & $0.51^{* *}$ & & $0.73^{* * *}$ & \\
\hline $\begin{array}{l}\text { Unemployment } \\
\text { rate t-2 }\end{array}$ & -0.26 & -0.30 & 0.15 & & 0.23 & \\
\hline Interest rate $\mathrm{t}=0$ & $-0.89^{* * *}$ & $-0.57^{* *}$ & 0.04 & $0.56^{* *}$ & $0.41^{*}$ & 0.36 \\
\hline Interest ratet-1 & $-0.80^{* * *}$ & -0.39 & -0.15 & & $0.40^{*}$ & \\
\hline
\end{tabular}

Notes: ${ }^{* *},{ }^{* *}, *$ : statistically significant at $1 \%, 5 \%$ and $10 \%$, respectively.

${ }^{13}$ The north comprises the Federal States of Bremen, Hamburg, Lower Saxony, and Schleswig-Holstein. Baden-Wuerttemberg and Bavaria make the southern region. East is the territory of the former socialist German Democratic Republic (GDR) plus the former West Berlin and includes the Federal States of Berlin, Brandenburg, Mecklenburg-Pomerania, Saxony, Saxony-Anhalt, and Thuringia. The western region comprises Hesse, North Rhine-Westphalia, Rhineland-Palatinate, and Saarland. 
Figure 2: Unemployment rates (upper four lines) and development of real GDP (lower four lines) in the four regions

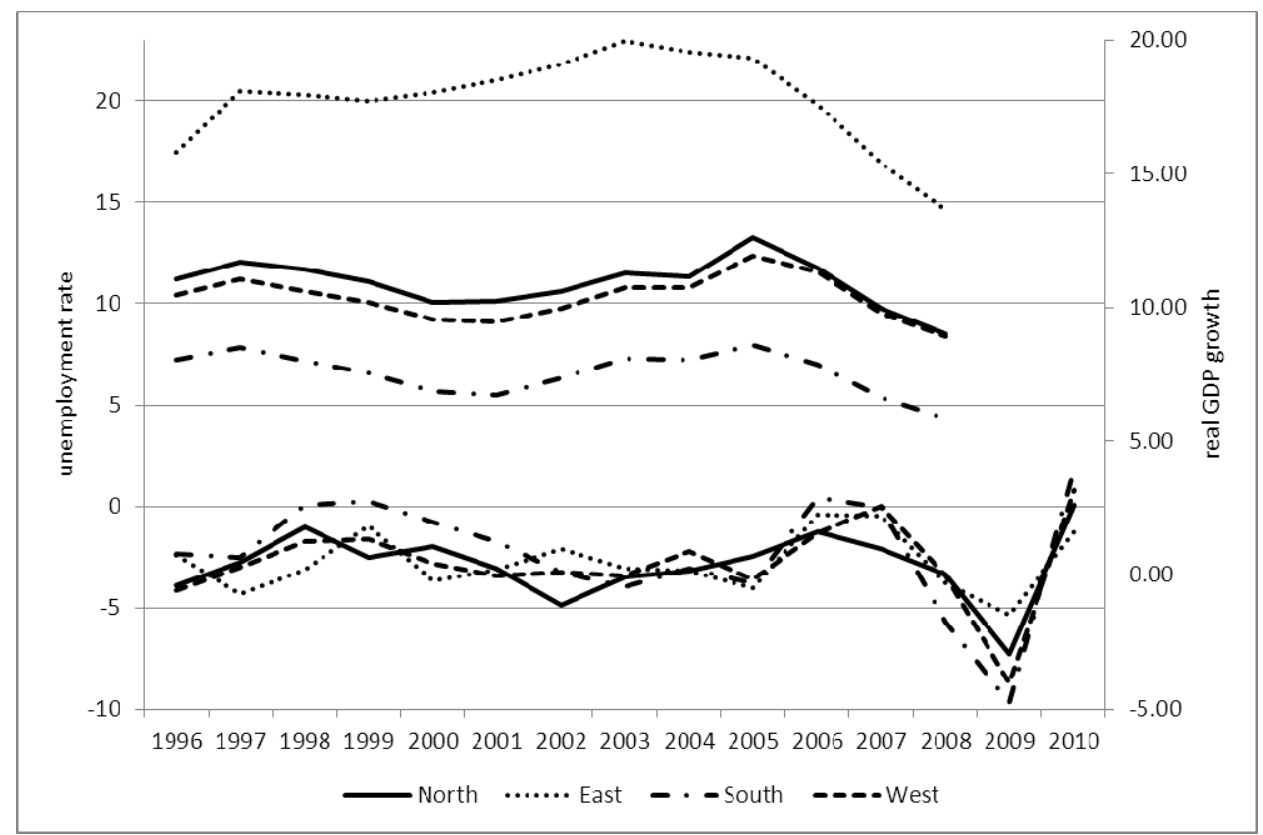

Over the observation period, the level of unemployment was highest in East Germany and lowest in the south of the country (Figure 2 ). In all four regions the unemployment rate increased in the early 2000s, peaked around 2005 and then declined through the end of the observation period. The figures for GDP growth show rather similar levels and developments in all four regions. The largest real GDP growth rates were reached in the years 2006/2007. Subsequently, the economic crisis of the years 2008/2009 led to a sharp decline of real GDP followed by a quite quick pick-up in the year 2010, with growth rates as high as before the recession (Figure 2).

\section{Empirical results}

\subsection{Econometric approach}

Given that the information on business registrations for the 16 German Länder are on an annual basis while the business formations reported by the Micro-Census are for quarters and must be aggregated to a 
larger geographical scale (North, South, East, and West), we conduct two different types of estimations. Taking the annual number of business registrations per economically active population as the dependent variable, we run regressions with the unemployment rate, the HP-filtered unemployment rate, real GDP growth, the HP-filtered real GDP, and interest rates as independent variables. The HP-filter is a frequently used statistical tool to decompose real GDP and the unemployment rate (Shimer, 2005) into a trend and a cyclical component. The two components are estimated in a way that over longer time periods the sum of the deviations of the cyclical component from the trend is close to zero thereby minimizing the variability of the growth component. The so called smoothing or HP filter parameter determines the allowed variability of the growth component. The larger the HP filter parameter, the smoother the trend component is. Following Ravn and Uhlig (2002), a HP filter parameter of 6.25 is used for annual data, and a parameter of 1600 for quarterly data. ${ }^{14}$

In order to account for the break in the Business Registration Statistic in the year 2003, we include a dummy variable (before $2003=$ $0 ; 2003$ and later = 1). A Breitung panel stationarity test (Breitung, 2000) reveals that our dependent variable, the number of business registrations per economically active population, is stationary when this dummy variable is included. ${ }^{15}$ All of the explanatory variables are also stationary. These variables are included with a time lag of one period in order to avoid endogeneity problems. ${ }^{16}$ We thereby follow a common

\footnotetext{
${ }^{14}$ Using other plausible values of the HP filter parameter does not lead to any fundamental changes of the results.

${ }^{15}$ This corresponds well to the observation made for a number of countries that the levels of new business formation, at a national and at a regional level, tends to persist over longer periods of time. For analyses at a national level see Congregado, Golpe and Parker (2012) and Parker, Congregado and Golpe (2012). Investigations at the regional level include Andersson and Koster (2011), Fotopoulos (2013) and Fritsch and Wyrwich (2014).

${ }^{16}$ Other authors address endogeneity arising from simultaneity between entrepreneurship and economic output by using vector autoregressive models (VAR)
} 
approach in the literature to avoid simultaneity issues (Aschoff and Schmidt, 2008; Bania, et al., 2007; Åstebro, et al., 2013; Buch, et al., 2013). The fixed effects method is applied in order to control for all timeinvariant region-specific effects. ${ }^{17}$ The results for the business registration data are reported in Table 2.

In the second estimation, we use the quarterly data on business formations reported by the Micro-Census. Unfortunately, quarterly GDP data is only available for Germany as a whole and not for individual German states or regions. For this reason, we regress new business formation per economically active population on different lags of the quarterly unemployment rate, on lags of the HP filtered unemployment rate, and on interest rates. Because unemployment rates for successive quarters are highly correlated, we do not include more than one time lag into one regression in order to avoid multicollinearity problems. This strategy should reveal the average time lag that is relevant for new business formation being induced by unemployment. The results of the fixed effects estimations based on the information on new business formation taken from the Micro-Census are presented in Table 3.

\subsection{Estimation results and robustness checks}

The main aim of our analysis is to empirically investigate whether various macro-economic variables influence the number of ventured businesses and entries into self-employment. Tables 2, 3 and 4 contain

(Koellinger and Thurik (2012) and Plehn-Dujowich (2012)). Unfortunately, our main data source (business registrations) has too few observations for panel-VAR models. Instrumental variables are applied in this broader context by Glaeser et al. (2012) and Acs et al. (2012). However, their instrumental variables cannot be applied in our setting. As we could not identify a compelling instrument for unemployment, the cyclical component of GDP, or GDP growth for our regional setting, we chose the method of lagging. However, our secondary data source (entry into self-employment from the Micro-Census) has a time dimension which is sufficiently long for VAR models. We present the results of our VAR and a panel-VAR estimation in section 4.2.

${ }^{17}$ The Hausman test suggests that the application of the random effects estimation procedure would be inappropriate. 
the estimation results of our empirical analysis. We begin with the analysis of the data on business registrations. Based on this statistic, Table 2 presents evidence that the unemployment level of the previous year ( $\mathrm{t}-1)$ has a significantly positive effect on the level of business registrations. According to these results, a ten percent increase in the unemployment rate leads to a three to four percent increase in business registrations per active population in the following period (columns I and II). The unemployment rate of the penultimate year ( $t-2)$ proves not to be statistically significant (columns $\mathrm{V}$ and $\mathrm{VI}$ ). The coefficient of the cyclical component of the unemployment rate is also significantly positive for the previous year (columns III and IV) but not with a time lag of two years (t-2; columns VII and VIII).

With respect to GDP, we find no effect of GDP growth on the level of business registrations (columns I, III, V and VII of Table 2). However, we find that for German data there is a significant negative coefficient for the effect of the cyclical component of real GDP in the previous year (t-1; columns II and IV). The negative sign of the coefficient indicates that better than average economic conditions lead to lower numbers of business registrations per economically active population and vice versa. As for the unemployment rate, no statistically significant effect is found for the HP filtered GDP of the penultimate year (t-2; columns VI and VIII). The interest rate for enterprises and self-employed persons is not statistically significant in any specification when the business register data are used.

These observations clearly suggest that in Germany the level of unemployment as well as its deviation from the long term trend have a stimulating effect on the formation of new businesses. The observation that the deviation of GDP from the trend has a negative influence on start-up rates corresponds to the effect of unemployment on entrepreneurial entries if periods of high unemployment and recession should correspond in time. Overall, the first part of our analysis indicates that, new business formation is counter-cyclical. 
Table 2: The effect of unemployment, GDP, and interest rates on business registrations based on the data of the business register

\begin{tabular}{|c|c|c|c|c|c|c|c|c|}
\hline \multicolumn{9}{|c|}{ "Dependent Variable: Log business registrations } \\
\hline & I & II & III & IV & V & VI & VII & VIII \\
\hline $\begin{array}{l}\text { Log unemployment rate } \\
\text { t-1 }\end{array}$ & $\begin{array}{c}0.42^{\star \star *} \\
(0.15)\end{array}$ & $\begin{array}{l}0.29^{* *} \\
(0.15)\end{array}$ & - & - & - & - & - & - \\
\hline $\begin{array}{l}\text { Log unemployment rate } \\
\mathrm{t}-2\end{array}$ & - & - & - & - & $\begin{array}{c}0.01 \\
(0.16)\end{array}$ & $\begin{array}{l}0.03 \\
(0.19)\end{array}$ & - & - \\
\hline $\begin{array}{l}\text { HP log unemployment } \\
\text { rate t-1 }\end{array}$ & - & - & $\begin{array}{c}0.74^{* * *} \\
(0.29)\end{array}$ & $\begin{array}{r}0.51^{*} \\
(0.30)\end{array}$ & - & - & - & - \\
\hline $\begin{array}{l}\text { HP log unemployment } \\
\text { rate t-2 }\end{array}$ & - & - & - & - & - & - & $\begin{array}{l}-0.06 \\
(0.29)\end{array}$ & $\begin{array}{l}-0.13 \\
(0.33)\end{array}$ \\
\hline Real GDP growth $\mathrm{t}-1$ & $\begin{array}{r}-1.73 \\
(1.14)\end{array}$ & - & $\begin{array}{r}-1.04 \\
(1.10)\end{array}$ & - & - & - & - & - \\
\hline Real GD & - & - & - & - & $\begin{array}{l}-0.39 \\
(1.24)\end{array}$ & - & $\begin{array}{l}-0.35 \\
(1.24)\end{array}$ & - \\
\hline HP log real GDP t-1 & - & $\begin{array}{c}-3.49^{* *} \\
(1.58)\end{array}$ & - & $\begin{array}{c}-3.18^{\star *} \\
(1.67)\end{array}$ & - & - & - & - \\
\hline HP log real GDP t-2 & - & - & - & - & - & $\begin{array}{l}-0.30 \\
(1.97)\end{array}$ & - & $\begin{array}{l}-0.79 \\
(1.83)\end{array}$ \\
\hline Log interest rate $\mathrm{t}-1$ & $\begin{array}{l}-0.25 \\
(0.23)\end{array}$ & $\begin{array}{l}-0.18 \\
(0.23)\end{array}$ & $\begin{array}{l}-0.01 \\
(0.24)\end{array}$ & $\begin{array}{l}-0.02 \\
(0.24)\end{array}$ & $\begin{array}{l}-0.23 \\
(0.43)\end{array}$ & $\begin{array}{l}-0.22 \\
(0.24)\end{array}$ & $\begin{array}{l}-0.26 \\
(0.26)\end{array}$ & $\begin{array}{l}-0.26 \\
(0.26)\end{array}$ \\
\hline Constant & $\begin{array}{c}-3.67^{\star \star \star *} \\
(0.55)\end{array}$ & $\begin{array}{c}-4.12^{\star * \star} \\
(0.55)\end{array}$ & $\begin{array}{c}-5.05^{\star * \star} \\
(0.46)\end{array}$ & $\begin{array}{c}-5.04^{* * *} \\
(0.45)\end{array}$ & $\begin{array}{c}-4.55^{\star \star \star} \\
(0.52)\end{array}$ & $\begin{array}{c}-4.61^{* * *} \\
(0.58)\end{array}$ & $\begin{array}{c}-4.59^{* \star *} \\
(0.48)\end{array}$ & $\begin{array}{c}-4.59^{* * *} \\
(0.48)\end{array}$ \\
\hline Breakdummy & $\begin{array}{c}0.90^{* * *} \\
(0.06)\end{array}$ & $\begin{array}{c}0.92^{* * *} \\
(0.06)\end{array}$ & $\begin{array}{c}0.93^{* * *} \\
(0.06)\end{array}$ & $\begin{array}{c}0.93^{* * *} \\
(0.06)\end{array}$ & $\begin{array}{c}0.89^{* * *} \\
(0.06)\end{array}$ & $\begin{array}{c}0.89^{* * *} \\
(0.07)\end{array}$ & $\begin{array}{c}0.88^{* * *} \\
(0.07)\end{array}$ & $\begin{array}{c}0.88^{\star \star \star} \\
(0.07)\end{array}$ \\
\hline $\mathrm{R}^{2}$ within & 0.77 & 0.77 & 0.76 & 0.77 & 0.76 & 0.76 & 0.76 & 0.76 \\
\hline
\end{tabular}

Notes: Fixed effects estimations for 16 German Länder with annual data, 224 or 208 observations; ${ }^{* * *},{ }^{* *},{ }^{*}$ : statistically significant at $1 \%, 5 \%$ and $10 \%$, respectively; standard errors in parentheses; fixed effects are always jointly significant at the one percent level. The high $\mathrm{R}^{2}$ is basically driven by the dummy variable.

The second data source the Micro-Census, presents quarterly data on entries into self-employment. The regression results confirm our previous finding with respect to the influence of unemployment levels on start-up behaviour. We again observe a significantly positive coefficient indicating that high (low) levels of unemployment should have a stimulating (weakening) effect on entries into self-employment (Table 3 - I). Specifically, a ten percent increase in the unemployment rate leads to an almost seven percent increase in entries into selfemployment in the following period. According to the coefficients for the different lags of the unemployment rate, this effect appears to be 
Table 3: The effect of quarterly unemployment and interest rates on entries into self-employment based on the micro-census

\begin{tabular}{|c|c|c|c|c|c|c|c|c|c|c|c|}
\hline \multicolumn{12}{|c|}{ Dependent Variable: Log entries into self-employment } \\
\hline \multicolumn{4}{|c|}{ I. Unemployment rate (unfiltered) } & \multicolumn{4}{|c|}{ II. HP filtered unemployment rate } & \multicolumn{4}{|c|}{$\begin{array}{l}\text { III. HP filtered unemployment rate - periods } \\
\text { with negative deviations from trend only }\end{array}$} \\
\hline & Coefficient & $\begin{array}{l}\text { Standard } \\
\text { error }\end{array}$ & $\begin{array}{c}\mathrm{R}^{2} \\
\text { within }\end{array}$ & & Coefficient & $\begin{array}{l}\text { Standard } \\
\text { error }\end{array}$ & $\begin{array}{c}\mathrm{R}^{2} \\
\text { within }\end{array}$ & & Coefficient & $\begin{array}{l}\text { Standard } \\
\text { error }\end{array}$ & $\begin{array}{c}\mathrm{R}^{2} \\
\text { within }\end{array}$ \\
\hline Log ur t-1 & $0.68^{* * *}$ & 0.08 & 0.61 & HP log ur t-1 & $0.94^{* * *}$ & 0.17 & 0.54 & HP log ur t-1 & $1.85^{\star * *}$ & 0.4 & 0.68 \\
\hline Log ir $\mathrm{t}-1$ & $-0.51^{* * *}$ & 0.09 & & Log ir $\mathrm{t}-1$ & $-0.36^{* * *}$ & 0.10 & & Log ir $\mathrm{t}-1$ & $-0.25^{* *}$ & 0.13 & \\
\hline Log ur t-2 & $0.70^{* * *}$ & 0.09 & 0.6 & HP log ur t-2 & $0.89^{* * *}$ & 0.18 & 0.53 & HP log ur t-2 & $1.23^{* * *}$ & 0.36 & 0.65 \\
\hline $\log$ ir $\mathrm{t}-1$ & $-0.45^{\star * *}$ & 0.09 & & Log ir t-1 & $-0.34^{* * *}$ & 0.10 & & $\log$ ir $\mathrm{t}-1$ & $-0.25^{\star}$ & 0.14 & \\
\hline Log ur t-3 & $0.67^{* * *}$ & 0.1 & 0.57 & HP log ur t-3 & $0.67^{* * *}$ & 0.19 & 0.5 & HP log ur t-3 & $0.78^{* *}$ & 0.31 & 0.63 \\
\hline Log ir t-1 & $-0.41^{* * *}$ & 0.09 & & Log ir $\mathrm{t}-1$ & $-0.37^{* * *}$ & 0.11 & & Log ir $t-1$ & $-0.29^{* *}$ & 0.14 & \\
\hline Log ur t-4 & $0.60^{* * *}$ & 0.11 & 0.54 & HP log ur t-4 & $0.38^{*}$ & 0.2 & 0.47 & HP log ur t-4 & 0.44 & 0.3 & 0.61 \\
\hline $\log$ ir $\mathrm{t}-1$ & $-0.38^{* * *}$ & 0.10 & & Log ir t-1 & $-0.43^{* * *}$ & 0.11 & & $\log$ ir $\mathrm{t}-1$ & $-0.32^{* *}$ & 0.14 & \\
\hline Log ur t-5 & $0.50^{* * *}$ & 0.12 & 0.51 & HP log ur t-5 & 0.03 & 0.21 & 0.46 & HP log ur t-5 & 0.07 & 0.3 & 0.6 \\
\hline Log ir $\mathrm{t}-1$ & $-0.38^{* * *}$ & 0.10 & & Log ir t-1 & $-0.52^{* * *}$ & 0.12 & & Log ir t-1 & $-0.38^{* *}$ & 0.15 & \\
\hline
\end{tabular}

Notes: Independent variables: ur - unemployment rate, ir - interest rates. Quarterly fixed effects estimation with seasonal dummy variables; regions North, South, East, West; T=49 (Q1 $1997-$ Q1 2009); ${ }^{* * *},{ }^{* *},{ }^{*}$ : statistically significant at $1 \%, 5 \%$ and $10 \%$, respectively; seasonal dummy variables are always jointly significant at the one percent level; coefficients from individual estimations (not jointly estimated); number of observations in regression with negative deviations from trend only $=96$. 
largest during the first four quarters and remains significantly positive up to six quarters. In the following quarter the coefficient is no longer significant. The cyclical component of the unemployment rate shows a similar pattern (Table $3-$ II). The positive coefficients for the first quarters imply that more people decide to start their own business when the unemployment rate is above its long-term trend, fewer people do so when the unemployment rate is below its long-term trend. In this analysis, information on GDP cannot be included since the quarterly information is not available at the Länder-level. Interestingly enough, when using the data on the Micro-Census the effect of the interest rate in the regression results presented in Table 3 is statistically significant with a negative sign. This indicates that higher interest rates lead to lower levels of new business creation and vice versa, as expected.

In a next step, we test whether the effects of unemployment and interest rates on the level of entries into self-employment are symmetric or whether there are different intensities in recessions and in boom periods. Therefore, we regress entries into self-employment separately on positive and negative deviations of the unemployment rate from its trend. ${ }^{18}$ We find that negative deviations have a statistically significant positive effect on the level of new business formation (Table 3-III) while unemployment rates above the long-term trend have no statistically significant effect. ${ }^{19}$ The statistically significant positive effect of negative deviations of the unemployment rate from its trend implies lower levels of new business formation at times when the unemployment rate is below 'normal.' This means that employment opportunities lead to reduced start-up activities while unemployment above the trend does not induce significantly more start-ups above 'normal.'

\footnotetext{
${ }^{18}$ Since the GDP data for Länder are only available on a yearly basis, there are not enough cases in our data to allow for this type of analysis for positive or negative deviations from the GDP trend.

${ }^{19}$ The results for the positive deviations are not presented in Table 3 due to their nonsignificance.
} 
Table 4: The effect of unemployment and GDP on business registrations with controls based on the business register

\begin{tabular}{|c|c|c|c|c|}
\hline \multicolumn{5}{|c|}{ Dependent Variable: Log business registrations } \\
\hline & I & II & III & IV \\
\hline Log unemployment rate $\mathrm{t}-1$ & $\begin{array}{l}0.42^{* *} \\
(0.14)\end{array}$ & & & \\
\hline HP log unemployment rate $\mathrm{t}-1$ & & $\begin{array}{c}0.79^{* * *} \\
(0.27)\end{array}$ & & \\
\hline Real GDP growth $\mathrm{t}-1$ & & & $\begin{array}{l}-1.16 \\
(1.09)\end{array}$ & \\
\hline HP log real GDP t-1 & & & & $\begin{array}{r}-5.19^{\star \star \star} \\
(1.47)\end{array}$ \\
\hline Log difference patent intensity & $\begin{array}{l}0.31^{*} \\
(0.18)\end{array}$ & $\begin{array}{c}0.29 \\
(0.18)\end{array}$ & $\begin{array}{l}0.31^{*} \\
(0.19)\end{array}$ & $\begin{array}{c}0.32^{*} \\
(0.18)\end{array}$ \\
\hline Log self-employment rate & & & $\begin{array}{l}0.15^{\star *} \\
(0.07)\end{array}$ & \\
\hline Constant & $\begin{array}{c}-4.2^{* * *} \\
(0.31)\end{array}$ & $\begin{array}{c}-5.10^{* * *} \\
(0.03)\end{array}$ & $\begin{array}{c}-4.7^{* * *} \\
(0.19)\end{array}$ & $\begin{array}{c}-5.11^{* * *} \\
(0.03)\end{array}$ \\
\hline Breakdummy & $\begin{array}{c}1.0 \\
(0.04)^{\star * \star}\end{array}$ & $\begin{array}{c}0.97^{\star * \star} \\
(0.04)\end{array}$ & $\begin{array}{c}0.94^{* * *} \\
(0.04)\end{array}$ & $\begin{array}{c}0.98^{* * *} \\
(0.04)\end{array}$ \\
\hline R2 within & 0.79 & 0.79 & 0.79 & 0.80 \\
\hline
\end{tabular}

Notes: Fixed effects estimations with 192 observations. ${ }^{* * *},{ }^{* *},{ }^{*}$ : statistically significant at $1 \%, 5 \%, 10 \%$, respectively; standard errors in parentheses.

In order to further test the robustness of our results beyond the analysis with two completely different data sets we run one further type of regression where we include two variables that control for determinants of entry other than unemployment. The first variable, the self-employment rate, reflects the entrepreneurship capital or the entrepreneurial 'culture' in a region (Audretsch and Keilbach, 2004; Fritsch and Wyrwich, 2014). This variable accounts for the observation that there is a pronounced tendency of a long term stability of relatively high or relatively low regional levels of new business formation. The second variable, patent intensity, is the number of patent applications over active population, and represents the generation of knowledge that may constitute a basis for opportunity start-ups. As patent intensity turns out to be non-stationary and may result in spurious regression, we used the stationary first log differences. The results (Table 4) partly confirm earlier analyses that found a considerable effect of regional 
$R \& D$ and of the level of new business formation in previous years (Fritsch and Wyrwich, 2014). More importantly, the results of the robustness checks show that all variables that have been statistically significant in the baseline models, i.e. the unemployment rate and its cyclical component, the cyclical component real GDP remain statistically significant with the same signs as in the baseline model.

As described in Section 4.1, we started our econometric approach by using lagged variables in order to avoid any simultaneity issues. The vector-autoregressive model (VAR), as alternative method to solve the endogeneity problem, cannot reasonably be applied to the business registrations as the number of observations is too small. However, our second data source, entries into self-employment from the MicroCensus, is available for a larger number of observations. Thus, to further test the robustness of our results presented in Table 3, we apply models where all variables are treated as endogenous, i.e. the current level of each variable (in our case entries into self-employment, unemployment rates and interest rates) is explained by its own past and by past observations of the other variables in the system. Similar to Koellinger and Thurik (2012), we aggregate observations across the four German regions, i.e. we work with time series for Germany as a whole, and estimate a VAR for the period from the $3^{\text {rd }}$ quarter of 1997 to the $1^{\text {st }}$ quarter of 2009. The estimation presented in Table 5 corresponds to the estimation in Table 3-I. The optimal lag length in both VAR models as suggested by the Hannan-Quinn (1979) and Schwarz (1978) information criteria is one period..$^{20}$

The results fully support our previous findings. The coefficient of the unemployment rates in Table 5-I is almost the same as in Table 3-I and

\footnotetext{
${ }^{20}$ A VAR model of the order 1 has the following form $x_{t}=a_{1} x_{t-1}+\varepsilon_{t}$ where $x_{t}$ is the vector of endogenous variables (entries into self-employment, unemployment rate and interest rates), and $a_{1}$ represents the vector of coefficients. The number of lags included in the system is 1.
} 
suggests a positive effect of the unemployment rate on entry into selfemployment. Also interest rates unfold the same significant effect on entries into self-employment.

Table 5: Vector Autoregressive Model, using aggregated data on quarterly entries into self-employment, the unemployment rate and interest rates based on the micro-census

\begin{tabular}{|c|c|c|c|c|c|c|c|c|}
\hline \multicolumn{3}{|c|}{$\begin{array}{l}\text { I. Log entries into self-employment } \\
\text { entry }\end{array}$} & \multicolumn{3}{|c|}{$\begin{array}{l}\text { II. Log unemployment rate } \\
\text { ur }\end{array}$} & \multicolumn{3}{|c|}{$\begin{array}{l}\text { III. Log interest rates } \\
\text { ir }\end{array}$} \\
\hline & Coefficient & $\begin{array}{l}\text { Standard } \\
\text { error }\end{array}$ & & Coefficient & $\begin{array}{l}\text { Standard } \\
\text { error }\end{array}$ & & Coefficient & $\begin{array}{l}\text { Standard } \\
\text { error }\end{array}$ \\
\hline entry(t-1) & $0.33^{* *}$ & 0.14 & entry(t-1) & $0.07^{*}$ & 0.04 & entry(t-1) & 0.009 & 0.04 \\
\hline $\mathrm{ur}(\mathrm{t}-1)$ & $0.65^{\star * *}$ & 0.17 & $\operatorname{ur}(\mathrm{t}-1)$ & $0.97^{* * *}$ & 0.05 & $\mathrm{ur}(\mathrm{t}-1)$ & -0.01 & 0.05 \\
\hline $\operatorname{ir}(t-1)$ & $-0.34^{* *}$ & 0.15 & $\operatorname{ir}(\mathrm{t}-1)$ & $0.12^{* * *}$ & 0.04 & $\operatorname{ir}(\mathrm{t}-1)$ & $0.98^{* * *}$ & 0.05 \\
\hline
\end{tabular}

Notes: Three variable VAR model using aggregated seasonally adjusted data; T=49 (Q1 1997 - Q1 2009); ***, ** statistically significant at $1 \%, 5 \%$ and $10 \%$, respectively, VAR(1), as suggested by the Hannan-Quinn and Schwe information criteria.

In a next step we estimate a panel-VAR with regional fixed-effects that has the advantage to account for unobserved region specific heterogeneity. ${ }^{21}$ For comparability reasons we use the same lag specification as for VAR with aggregated data.

Again, the results support our initial findings. Table 6-I shows that the unemployment rates have a significantly positive and the interest rates a significantly negative effect on entries into self-employment. Overall, the VAR and the panel-VAR estimation support the use of lagged explanatory variables to solve possible endogeneity problems, as the results are quite similar.

\footnotetext{
${ }^{21}$ For the panel-VAR estimation in Stata, we use the pvar.ado file created by Inessa Love (Love and Zicchino, 2006).
} 
Table 6: Fixed-effects panel-Vector Autoregressive Model, using aggregated data on quarterly entries into self-employment, the unemployment rate and interest rates based on the microcensus

\begin{tabular}{|c|c|c|c|c|c|c|c|c|}
\hline \multicolumn{3}{|c|}{$\begin{array}{l}\text { I. Log entries into self-employment } \\
\text { entry }\end{array}$} & \multicolumn{3}{|c|}{$\begin{array}{l}\text { II. Log unemployment rate } \\
\text { ur }\end{array}$} & \multicolumn{3}{|c|}{$\begin{array}{l}\text { III. Log interest rates } \\
\text { ir }\end{array}$} \\
\hline & Coefficient & $\begin{array}{c}\text { Standard } \\
\text { error }\end{array}$ & & Coefficient & $\begin{array}{l}\text { Standard } \\
\text { error }\end{array}$ & & Coefficient & $\begin{array}{l}\text { Standard } \\
\text { error }\end{array}$ \\
\hline entry(t-1) & $0.70^{* *}$ & 0.31 & entry(t-1) & -0.09 & 0.08 & entry $(t-1)$ & 0.03 & 0.06 \\
\hline $\mathrm{ur}(\mathrm{t}-1)$ & $0.48^{* * *}$ & 0.17 & $\operatorname{ur}(\mathrm{t}-1)$ & $0.99^{* * *}$ & 0.04 & $\operatorname{ur}(\mathrm{t}-1)$ & -0.02 & 0.04 \\
\hline $\operatorname{ir}(t-1)$ & $-0.34^{* * *}$ & 0.09 & ir(t-1) & 0.01 & 0.03 & $\operatorname{ir}(\mathrm{t}-1)$ & $0.98^{* * *}$ & 0.02 \\
\hline
\end{tabular}

Notes: Three variable fixed-effects panel-VAR model for the German regions North, South, East, West, observat 2009);GMM estimation, region specific effects were eliminated prior to the estimation (Helmert transformation); s ${ }^{* * *},{ }^{* *},{ }^{*}$ : statistically significant at $1 \%, 5 \%$ and $10 \%$, respectively,

Summarizing, our results provide evidence for the following insights:

(1) Unemployment rates positively influence entrepreneurial entry rates measured either in terms of new business formation or in terms of entry into self-employment, indicating that unemployment has a countercyclical influence on entrepreneurial entries.

(2) The relationship between the unemployment rate and the entry into self-employment is asymmetric in the sense that below average unemployment leads to significantly lower levels of entries into selfemployment while unemployment above the trend does at least not induce significantly more start-ups above normal, pointing to a certain asymmetry which we term "low unemployment retain effect."

(3) GDP development has a counter-cyclical influence on business formation as well.

(4) When using quarterly data, there is a statistically significant negative relationship between the interest rate and the entry into selfemployment. 


\section{Related approaches, possible objections and future research}

Our main result, the counter-cyclical influence of macroeconomic variables and more specifically of unemployment on new business formation is in line with some recent research. For example, Fairlie (2013) finds for U.S. Metropolitain Statistical Areas that higher unemployment rates increase the probability to start businesses. Koellinger and Thurik (2012) in their investigation of 22 OECD countries over the 1972-2007 period identify a positive effect of unemployment on business ownership rates. Román, et al. (2013), in an analysis based on the European Community Household Panel, find that only ownaccount self-employment is positively affected by the unemployment rate while employer self-employment is pro-cyclical. As this analysis is limited to start-ups out of unemployment, these findings can, however, not be directly compared to ours.

Future research of the effect of macro-economic development on new business formation - not only in Germany - should try to distinguish between different types of entrepreneurs in order to find out differences between founders and the firms they create during recessions and in boom periods. Are innovative entries more likely to appear during boom periods or in recessions? Do firms set up in periods of macroeconomic prosperity create more jobs in subsequent years than entries during periods of low growth and high unemployment? ${ }^{22}$ No doubt that the issue of quality of start-ups in terms of innovativeness, persistence, and growth over the business cycle

\footnotetext{
22 Earle and Sakova (2000) and Román, Congregado and Millán (2013) focus on the question of whether those firms starting without any employees exhibit different cyclical behavior than firms that start with employees. However, looking at the characteristics of firms at the time of the establishment without a further analysis of start-up performance over the first two or three years may lead to false conclusions. We know from previous panel data analyses in Germany that a certain share of individuals starting as solo-entrepreneurs create further jobs after the venturing of the business, many in the first year (see Fritsch, Kritikos and Rusakova, 2012), even if they come out of unemployment (Caliendo, Kritikos, 2010).
} 
needs further investigation. This kind of analysis, however, requires different empirical approaches and considerably more detailed panel data than we have currently available.

Since we have - in contrast to most previous research - based our analysis on gross entry into self-employment it would be also interesting to know more about the exits from self-employment that constitute the other side of the coin. Information on both sides would provide us with a comprehensive picture and would enable a better understanding of the results of those approaches that analyze the development of net-entry. A further limitation of our study is the short time-series with only a limited number of observations. Availability of longer time-series and inclusion of additional control variables may provide further insights into the relationship between macro-economic conditions, industry- as well as region-specific factors, and individual level characteristics. ${ }^{23}$

Last but not least, there can be little doubt that entrepreneurship may have a pronounced positive effect on growth by introducing innovation, contesting the position of incumbents, and by creating new jobs (see Fritsch, 2013). For this reason, it is plausible to assume that it is not only the business cycle affecting new business formation but also that increased start-up activity may feed-back to the macro-economic level by stimulating economic development (see Koellinger and Thurik, 2012). Hence, an empirical analysis should account for both directions of causality. Since the effect of new business formation on development takes up to ten years to unfold (Fritsch, 2013), longer time-series of data than we have currently available are needed to fully capture such effects.

${ }^{23}$ That the regional environment may play an important role is suggested by Román, Congregado and Millán (2013), who find that there are interaction effects between certain socio-demographic characteristics and the macro-economic variables that influence transitions into self-employment during different periods of the business cycle. Important control variables at the macro-level that should be included in future research are employment protection measures, indicators for entrepreneurship policy, and employment incentives. 


\section{Conclusion}

We analyze to what extent variables representing the business cycle particularly GDP, unemployment, and interest rates -affect gross entry into entrepreneurship in Germany. Our results show that the rate of unemployment exhibits a significant counter-cyclical influence on entry rates into entrepreneurship. This effect is asymmetric in the sense that unemployment rates below the longer-term trend lead to lower levels of new business formation while unemployment above the trend has no significant "push" effect. We conclude that this indicates a "low unemployment retain effect." We also find a counter-cyclical effect for deviations of GDP from its trend. Accordingly, people are induced to become self-employed during recessions whereas there are lower levels of new business formation when the level of GDP is above the trend. As such the growth rate of real GDP has no statistically significant effect on gross entry. In the same direction, we also find a negative relationship between the interest rate and the entry into selfemployment.

Thus, all our findings point to counter-cyclical effects of macroeconomic variables on new business formation, providing evidence that entrepreneurs are not only important for an economy because they introduce new products to the markets, contest established market positions and create jobs, but because they also may play a role as stabilizers throughout the business cycle. 


\section{References}

Acs, Z.J. and D.B. Audretsch (2003): Innovation and Technological Change. In: Z.J. Acs and D.B. Audretsch (eds.): Handbook of Entrepreneurship Research, Boston: Kluwer, 55-79.

Acs, Z., D. Audretsch, P. Braunerhjelm and B. Carlsson (2012): Growth and Entrepreneurship. Small Business Economics, 39, 289-300.

Andersson, M. and S. Koster (2011): Sources of persistence in regional start-up rates-Evidence from Sweden. Journal of Economic Geography, 11, 179-201.

Aschhoff, B. and T. Schmidt (2008): Empirical evidence on the success of R\&D cooperation-Happy together? Review of Industrial Organization, 33, 41-62.

Åstebro, T., Braunerhjelm, P. and A. Broström (2013): Does academic entrepreneurship pay? Industrial and Corporate Change, 22, 281311.

Audretsch, D.B., and M. Keilbach (2004): Entrepreneurship capital and economic performance. Regional Studies, 38, 949-959..

Audretsch, D.B. and A.R. Thurik (2000): Capitalism and democracy in the 21st Century: from the managed to the entrepreneurial economy. Journal of Evolutionary Economics, 10, 153-167.

Bania, N., Gray, J.A. and J.A. Stone (2007): Growth, taxes, and government expenditures: Growth hills for U.S. states. National Tax Journal, LX, 193-204.

Barlevy, G. (2007): On the cyclicality of Research and Development. American Economic Review, 97, 1131-1164.

Blanchflower, D. (2000): Self-employment in OECD countries. Labour Economics, 7, 471-505.

Blanchflower, D. and A. Oswald (1998): What makes an entrepreneur? Journal of Labor Economics, 6, 26-60.

Block, J., L. Hoogerheide and A.R. Thurik (2012): Education and Entrepreneurial Choice: Evidence from an Instrumental Variables Regression. International Small Business Journal, (in press).

Breitung, J. (2000): The local power of some unit root tests for panel data. Advances in Econometrics, Volume 15: Nonstationary Panels, Panel Cointegration, and Dynamic Panels, ed. B. H. Baltagi, 161178. Amsterdam: JAY Press.

Brüderl, J., P. Preisendörfer and R. Ziegler (2009): Der Erfolg neugegründeter Betriebe. 3rd edition, Berlin: Duncker \& Humblot.

Buch, C., Koch, C.T., and M. Koetter (2013): Do banks benefit from internationalization? Revisiting the market power-risk nexus. Review of Finance, 17, 1401-1435. 
Caballero, R.J. and M.L. Hammour (1994): The Cleansing Effect of Recessions. American Economic Review, 84, 1350-1368.

Caliendo, M., F.M. Fossen and A.S. Kritikos (2009): Risk Attitudes of Nascent Entrepreneurs. Small Business Economics, 32, 153-167.

Caliendo, M., F.M. Fossen and A.S. Kritikos (2010): The Impact of Risk Attitudes on Entrepreneurial Survival. Journal of Economic Behavior and Organization, 76, 45-63.

Caliendo, M., F.M. Fossen and A.S. Kritikos (2012): Trust, Positive Reciprocity, and Negative Reciprocity: Do These Traits Impact Entrepreneurial Dynamics? Journal of Economic Psychology, 33, 394-409.

Caliendo, M., F.M. Fossen and A.S. Kritikos (2013): Personality Characteristics and the Decisions to Become and Stay SelfEmployed. Small Business Economics, DOI 10.1007/s11187-0139514-8.

Caliendo, M. and A.S. Kritikos (2010): Start-ups by the Unemployed: Characteristics, Survival and Direct Employment Effects. Small Business Economics 35, 71-92.

Carrasco, R. (1999): Transitions to and from Self-Employment in Spain: an Empirical Analysis. Oxford Bulletin of Economics and Statistics, 61, 315-341.

Congregado, E., A.A. Golpe and S.C. Parker (2012): The dynamics of entrepreneurship: hysteresis, business cycles and government policy. Empirical Economics, 43, 1239-1261.

Davidsson, P. (2004): Researching Entrepreneurship. Springer: New York.

De Clercq, D. and P. Arenius (2006): The Role of Knowledge in Business Start-up Activity. International Small Business Journal, 24, 339-358.

Earle, J.S. and Z. Sakova (2000): Business start-ups or disguised unemployment? Evidence on the character of self-employment from transition economies. Labour Economics, 7, 575-601.

Fairlie, R.W. (2013): Entrepreneurship, Economic Conditions, and the Great Recession. Journal of Economics and Management Strategy, 22, 207-231.

Foti, A. and M. Vivarelli (1994): An econometric test of the selfemployment model-the case of Italy. Small Business Economics, 6, 81-93.

Fotopoulos, G. (2013): On the spatial stickiness of UK New firm formation rates. Journal of Economic Geography, DOI 10.1093/jeg/lbt011.

Francois, P., Lloyd-Ellis, H (2003): Animal Spirits Through Creative Destruction, American Economic Review, 93, 530-550. 
Fritsch, M. (2013): New Business Formation and Regional Development-A Survey and Assessment of the Evidence. Foundations and Trends in Entrepreneurship, 9, 249-364.

Fritsch, M., R. Grotz, U. Brixy, M. Niese and A. Otto (2002): Die statistische Erfassung von Gründungen in Deutschland - ein Vergleich von Beschäftigtenstatistik, Gewerbeanzeigenstatistik und den Mannheimer Gründungspanels. Allgemeines Statistisches Archiv, 86, 87-96.

Fritsch, M., A.S. Kritikos and A. Rusakova (2012): Who Starts a Business and who is Self-Employed in Germany. IZA Discussion Paper Nr. 6326.

Fritsch, M. and M. Wyrwich (2014): The Long Persistence of Regional Levels of Entrepreneurship: Germany 1925 to 2005. Regional Studies, 48 (forthcoming).

Georgellis, Y. and H.J. Wall (2000): What Makes a Region Entrepreneurial? Evidence from Britain. Annals of Regional Science 34, 385-403.

Glaeser, E. L., S.P. Kerr and W.R. Kerr (2012): Entrepreneurship and Urban Growth: An Empirical Assessment with Historical Mines. NBER Working Paper Series 18333.

Grant, D. (1996): The Political Economy of New Business Formation Across the American States 1970-1985. Social Science Quarterly, $77,28-42$.

Hannan, E.J.and B.G. Quinn (1979): The Determination of the Order of an Autoregression. Journal of the Royal Statistical Society. Series B (Methodological), 41, 190-195.

Hessels, J.; M. van Gelderen, R.A. Thurik (2008): Entrepreneurial Aspirations, Motivations, and their Drivers. Small Business Economics 31: 323-339.

Hodrick, R.J. and E.C. Prescott (1997): Postwar U.S. Business Cycles: An Empirical Investigation. Journal of Money, Credit and Banking, 29, 1-16.

Koellinger, P. and A.R. Thurik (2012): Entrepreneurship and the Business Cycle. Review of Economics and Statistics, 94, 11431156.

Leiner, R. (2002): Die Gewerbeanzeigenstatistik. In: M. Fritsch and R. Grotz (eds.): Das Gründungsgeschehen in Deutschland, Heidelberg: Physica, 103-127.

Levesque, M. and M. Minniti (2006): The Effect of Ageing on Entrepreneurial Behavior. Journal of Business Venturing, 21, 177-194.

Love, I. and L. Zicchino (2006): Financial development and dynamic investment behavior: Evidence from panel VAR. The Quarterly Review of Economics and Finance, 46, 190-210. 
Nickell, S. (1996): Competition and corporate Performance. Journal of Political Economy, 104, 724-746.

Oberlander, W. (2004): Freie Berufe: positive Zahlen, schwindende Attraktivität. Nürnberg: Informationen des IFB Nürnberg.

Parker, Simon (2009): The Economics of Entrepreneurship. Cambridge: Cambridge University Press.

Parker, S.C., E. Congregado, and A.A. Golpe (2012): Testing for hysteresis in entrepreneurship in 23 OECD countries. Applied Economics Letter, 19, 61-66.

Plehn-Dujowich, J.M. (2012): The Dynamic Relationship between Entrepreneurship, Unemployment, and Growth: Evidence from U.S. Industries. Report.

Rampini, A. (2004): Entrepreneurial activity, risk, and the business cycle, Journal of Monetary Economics, 51, 555-573.

Ravn, M.O. and H. Uhlig (2002): On Adjusting the Hodrick-Prescott Filter for the Frequency of Observations. Review of Economics and Statistics, 84, 371-376.

Robson, M.T. (1998): Self-Employment in the UK Regions, Applied Economics 30, 313-322.

Román, C., E. Congregado and J.M. Millán (2013): Start-up incentives: Entrepreneurship policy or active labour market programme? Journal of Business Venturing, 28, 151-175.

Schwarz, G. (1978): Estimating the Dimension of a Model. The Annals of Statistics, 6, 461-464.

Shimer, R. (2005): The Cyclical Behavior of Equilibrium Unemployment and Vacancies. American Economic Review, 95, 25-49.

Shleifer, A. (1986): Implementation Cycles. Journal of Political Economy, 94, 1163-1190

Statistisches Bundesamt (2009): Handbuch zum Mikrozensus. Wiesbaden: Statistische Bundesamt.

Tervo, H. (2006): Regional Unemployment, Self-Employment and Family Background. Applied Economics, 38, 1055-1062.

Tervo, H. and H. Niittykangas (1994): The Impact of Unemployment on New Firm Formation in Finland. International Small Business Journal, 13, 38-53.

Thurik, R., E. Stam and D.B. Audretsch (2013): The rise of the entrepreneurial economy and the future of dynamic capitalism. Technovation, 33, 302-310.

van Stel, A.; M. Carree, M. and A.R. Thurik (2005): The Effect of Entrepreneurial Activity on National Economic Growth. Small Business Economics, 24, 311-321. 


\section{Figures}

Figure 3: Annual number of business registrations and annual number of business formations reported in the Micro-Census

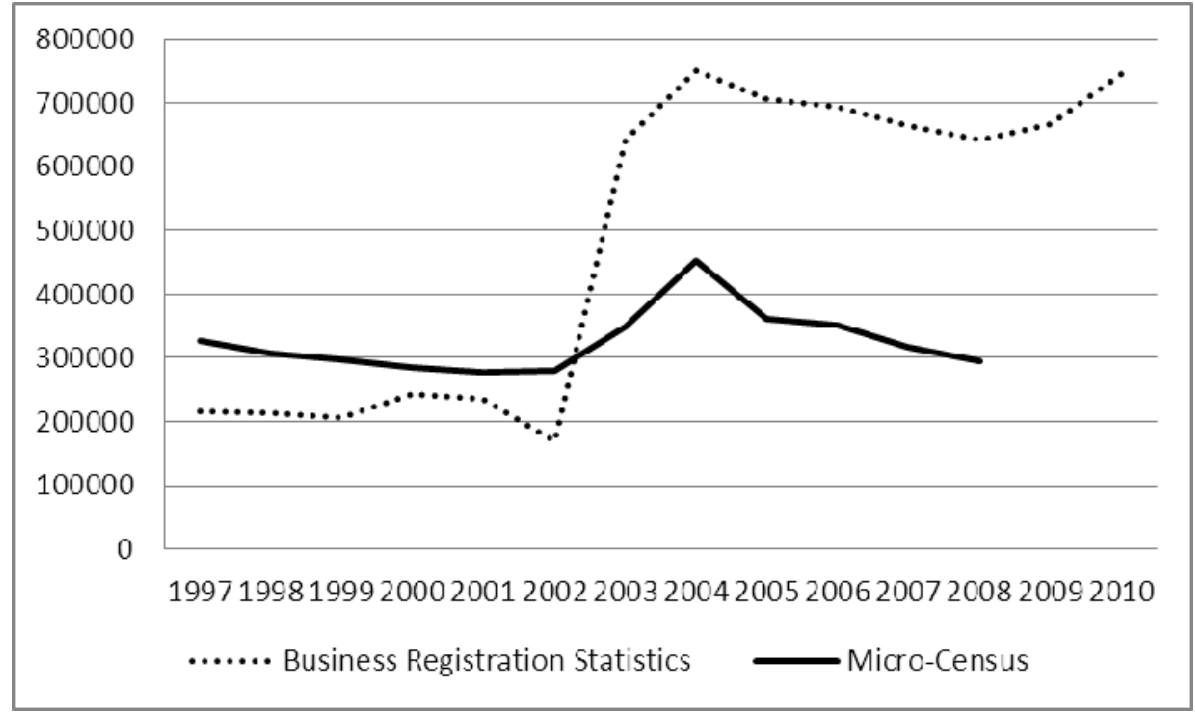

Figure 4: Unemployment rates and development of real GDP in the four regions

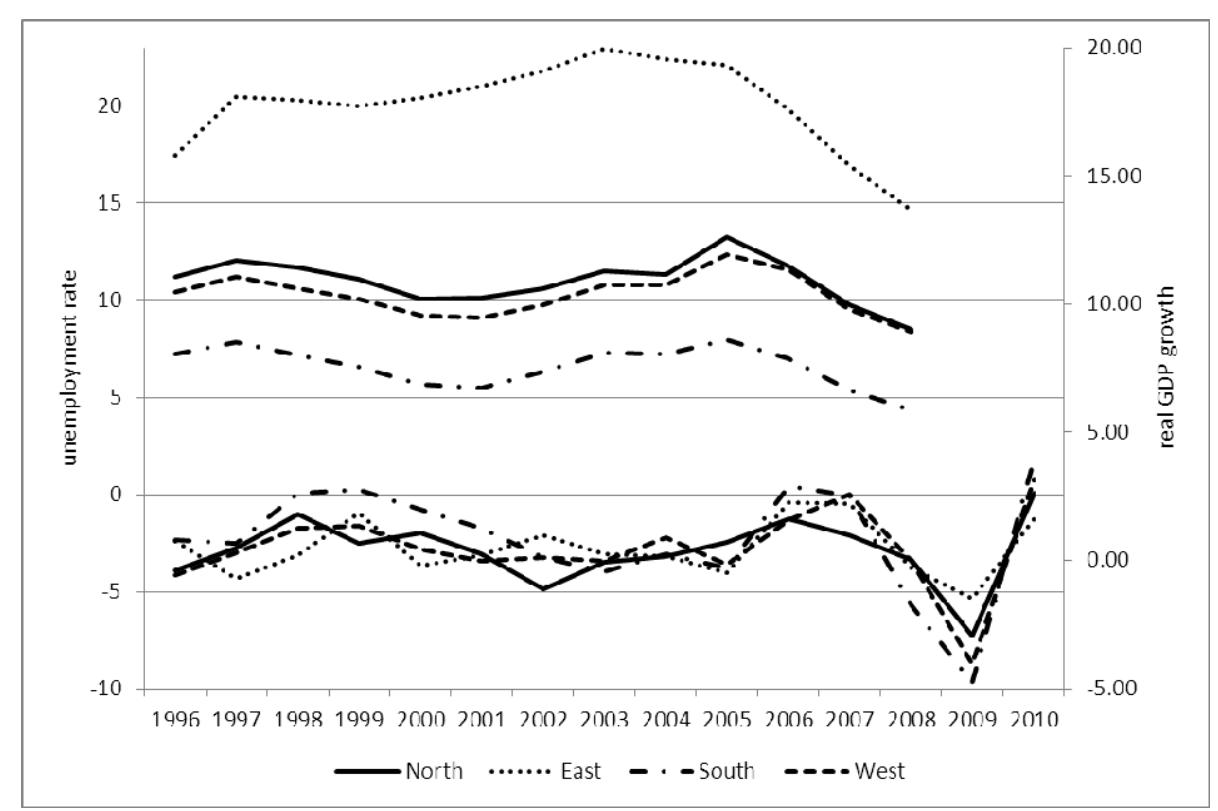




\section{Tables}

Table 5: Correlation analysis

\begin{tabular}{|c|c|c|c|c|c|c|c|c|c|}
\hline & $\begin{array}{l}\text { Business } \\
\text { registrations } \mathrm{t}=0\end{array}$ & $\begin{array}{c}\text { New businesses } \\
\text { (Micro-Census) } t=0\end{array}$ & $\begin{array}{c}\text { Real GDP } \\
\text { growth } \\
t=0\end{array}$ & $\begin{array}{l}\text { Real GDP } \\
\text { growth t-1 }\end{array}$ & $\begin{array}{l}\text { Unemployment } \\
\text { rate } \mathrm{t}=0\end{array}$ & $\begin{array}{c}\text { Unemployment } \\
\text { rate } \mathrm{t}-1\end{array}$ & $\begin{array}{l}\text { Unemployment } \\
\text { rate } \mathrm{t}-2\end{array}$ & $\begin{array}{l}\text { Interest } \\
\text { rate } \mathrm{t}=0\end{array}$ & $\begin{array}{l}\text { Interest } \\
\text { ratet-1 }\end{array}$ \\
\hline Business registrations $\mathrm{t}=0$ & & $\begin{array}{c}\text { 1997-2008: } 0.69^{* * *} \\
\text { 1997-2002: } 0.04 \\
\text { 2003-2008: } 0.88^{* * *}\end{array}$ & -0.07 & -0.2 & -0.29 & -0.26 & -0.26 & $-0.89^{\star * *}$ & $-0.80^{* * *}$ \\
\hline $\begin{array}{l}\text { New businesses (Micro- } \\
\text { Census) } t=0\end{array}$ & $\begin{array}{c}\text { 1997-2008: } 0.69^{* * *} \\
\text { 1997-2002: } 0.04 \\
\text { 2003-2008: } 0.88^{* * *}\end{array}$ & & -0.1 & $-0.7^{* * *}$ & 0.41 & 0.28 & -0.3 & $-0.57^{* *}$ & -0.39 \\
\hline Real GDP growth $\mathrm{t}=0$ & -0.07 & -0.10 & & & 0.11 & $0.51^{* *}$ & 0.15 & 0.04 & -0.15 \\
\hline Real GDP growth t-1 & -0.20 & $-0.70^{\star * *}$ & & & & & & & \\
\hline Unemployment rate $\mathrm{t}=0$ & -0.29 & 0.41 & 0.11 & & & & & $0.41^{*}$ & $0.40^{*}$ \\
\hline Unemployment rate $\mathrm{t}-1$ & -0.26 & 0.28 & $0.51^{* *}$ & & & & & & \\
\hline Unemployment rate $\mathrm{t}-2$ & -0.26 & -0.30 & 0.15 & & & & & & \\
\hline Interest rate $\mathrm{t}=0$ & $-0.89^{\star * *}$ & $-0.57^{* *}$ & 0.04 & & $0.41^{*}$ & & & & \\
\hline Interest ratet-1 & $-0.80^{* * *}$ & -0.39 & -0.15 & & $0.40^{*}$ & & & & \\
\hline
\end{tabular}

Notes: ${ }^{\star \star *},{ }^{* *}$, *: statistically significant at $1 \%, 5 \%, 10 \%$, respectively. 
Table 6: The effect of unemployment, GDP, and interest rates on business registrations

\begin{tabular}{|c|c|c|c|c|c|c|c|c|}
\hline \multicolumn{9}{|c|}{ Dependent Var: Log business registrations } \\
\hline & 1 & II & III & IV & $\mathrm{V}$ & $\mathrm{VI}$ & VII & VIII \\
\hline Log unemployment rate $\mathrm{t}-1$ & $\begin{array}{l}0.41^{* *} \\
(0.14)\end{array}$ & & & & & & & \\
\hline Log unemployment rate $\mathrm{t}-2$ & & $\begin{array}{c}0.14 \\
(0.16)\end{array}$ & & & & & & \\
\hline HP log unemployment rate $\mathrm{t}-1$ & & & $\begin{array}{c}0.77^{\star * *} \\
(0.28)\end{array}$ & & & & & \\
\hline HP log unemployment rate $\mathrm{t}-2$ & & & & $\begin{array}{c}0.08 \\
(0.29)\end{array}$ & & & & \\
\hline Real GDP growth $\mathrm{t}-1$ & & & & & $\begin{array}{l}-0.68 \\
(1.12)\end{array}$ & & & \\
\hline Real GDP growth t-2 & & & & & & $\begin{array}{l}-1.39 \\
(1.41)\end{array}$ & & \\
\hline HP log real GDP t-1 & & & & & & & $\begin{array}{c}-4.73^{* * *} \\
(1.53)\end{array}$ & \\
\hline HP log real GDP t-2 & & & & & & & & $\begin{array}{l}-3.37^{*} \\
(1.83)\end{array}$ \\
\hline Interest rate $\mathrm{t}-1$ & $\begin{array}{c}-0.31 \\
(0.22)\end{array}$ & $\begin{array}{l}-0.25 \\
(0.23)\end{array}$ & $\begin{array}{c}-0.05 \\
(0.24)\end{array}$ & $\begin{array}{l}-0.25 \\
(0.25)\end{array}$ & $\begin{array}{l}-0.27 \\
(0.23)\end{array}$ & $\begin{array}{l}-0.26 \\
(0.23)\end{array}$ & $\begin{array}{l}-0.18 \\
(0.42)\end{array}$ & $\begin{array}{l}-0.23 \\
(0.23)\end{array}$ \\
\hline Constant & $\begin{array}{c}-3.61^{* * \star} \\
(0.53)\end{array}$ & $\begin{array}{c}-4.31^{* * *} \\
(0.52)\end{array}$ & $\begin{array}{c}-4.99^{* * *} \\
(0.44)\end{array}$ & $\begin{array}{c}-4.62^{\star * \star} \\
(0.46)\end{array}$ & $\begin{array}{c}-4.58^{* * \star} \\
(0.43)\end{array}$ & $\begin{array}{c}-4.60^{\star * *} \\
(0.43)\end{array}$ & $\begin{array}{c}-4.76^{\star * \star} \\
(0.42)\end{array}$ & $\begin{array}{c}-4.66^{* \star *} \\
(0.42)\end{array}$ \\
\hline Breakdummy & $\begin{array}{c}0.92^{* * *} \\
(0.06)\end{array}$ & $\begin{array}{l}0.91^{* * *} \\
(0.06)\end{array}$ & $\begin{array}{c}0.94^{* * *} \\
(0.06)\end{array}$ & $\begin{array}{c}0.90^{* * *} \\
(0.07)\end{array}$ & $\begin{array}{c}0.89^{* * *} \\
(0.06)\end{array}$ & $\begin{array}{c}0.90^{* * *} \\
(0.06)\end{array}$ & $\begin{array}{c}0.92^{* * *} \\
(0.06)\end{array}$ & $\begin{array}{c}0.92 \\
(0.06)\end{array}$ \\
\hline $\mathrm{R}^{2}$ within & 0.78 & 0.77 & 0.78 & 0.77 & 0.77 & 0.77 & 0.78 & 0.77 \\
\hline
\end{tabular}

Notes: Fixed effects estimations for 16 German Länder with annual data, 208 observations; ***, **, *: statistically significant at $1 \%, 5 \%, 10 \%$, respectively; standard errors in parentheses; Fixed effects are always jointly significant at the one percent level. 
Table 7: The effect of quarterly unemployment and interest rates on new business formation

\begin{tabular}{|c|c|c|c|c|c|c|c|c|c|c|c|}
\hline \multicolumn{12}{|c|}{$\begin{array}{l}\text { Dependent Variable: Log new businesses (Micro-Census) } \\
\text { Independent variables: ur - unemployment rate, ir - interest rates }\end{array}$} \\
\hline & Coefficient & $\begin{array}{c}\text { Standard } \\
\text { error }\end{array}$ & $\mathrm{R}^{2}$ within & & Coefficient & $\begin{array}{l}\text { Standard } \\
\text { error }\end{array}$ & $\mathrm{R}^{2}$ within & & Coefficient & $\begin{array}{l}\text { Standard } \\
\text { error }\end{array}$ & $\mathrm{R}^{2}$ within \\
\hline Log ur t-1 & $0.68^{* * *}$ & 0.08 & 0.61 & HP log ur t-1 & $0.94^{* * *}$ & 0.17 & 0.54 & HP log ur $<0 \mathrm{t}-1$ & $1.85^{* * *}$ & 0.4 & 0.68 \\
\hline Log ir t-1 & $-0.51^{* * *}$ & 0.09 & & Log ir t-1 & $-0.36^{\star * *}$ & 0.10 & & Log ir t-1 & $-0.25^{\star \star}$ & 0.13 & \\
\hline Log ur t-2 & $0.70^{* * *}$ & 0.09 & 0.6 & HP log ur t-2 & $0.89^{* * *}$ & 0.18 & 0.53 & HP log ur $<0$ t-2 & $1.23^{\star \star *}$ & 0.36 & 0.65 \\
\hline Log ir t-1 & $-0.45^{\star * *}$ & 0.09 & & Log ir t-1 & $-0.34^{* * *}$ & 0.10 & & Log ir t-1 & $-0.25^{*}$ & 0.14 & \\
\hline Log ur t-3 & $0.67^{* * *}$ & 0.1 & 0.57 & HP log ur t-3 & $0.67^{* * *}$ & 0.19 & 0.5 & HP log ur $<0$ t-3 & $0.78^{* *}$ & 0.31 & 0.63 \\
\hline Log ir $\mathrm{t}-1$ & $-0.41^{* * *}$ & 0.09 & & Log ir $t-1$ & $-0.37^{* * *}$ & 0.11 & & Log ir $\mathrm{t}-1$ & $-0.29^{* *}$ & 0.14 & \\
\hline Log ur t-4 & $0.60^{\star * *}$ & 0.11 & 0.54 & HP log ur t-4 & $0.38^{*}$ & 0.2 & 0.47 & HP log ur $<0$ t-4 & 0.44 & 0.3 & 0.61 \\
\hline Log ir $t-1$ & $-0.38^{* * *}$ & 0.10 & & Log ir $t-1$ & $-0.43^{\star * *}$ & 0.11 & & Log ir $t-1$ & $-0.32^{* *}$ & 0.14 & \\
\hline Log ur t-5 & $0.50^{\star * *}$ & 0.12 & 0.51 & HP log ur t-5 & 0.03 & 0.21 & 0.46 & HP log ur $<0$ t-5 & 0.07 & 0.3 & 0.6 \\
\hline Log ir t-1 & $-0.38^{* * *}$ & 0.10 & & Log ir $t-1$ & $-0.52^{\star * *}$ & 0.12 & & Log ir $t-1$ & $-0.38^{* *}$ & 0.15 & \\
\hline Log ur t-6 & $0.27^{*}$ & 0.14 & 0.48 & HP log ur t-6 & $-0.44^{* *}$ & 0.21 & 0.48 & HP log ur $<0$ t- 6 & -0.27 & 0.29 & 0.6 \\
\hline Log ir t-1 & $-0.46^{\star * *}$ & 0.11 & & Log ir t-1 & $-0.67^{* * *}$ & 0.12 & & Log ir $t-1$ & $-0.47^{* * *}$ & 0.16 & \\
\hline Log ur t-7 & -0.02 & 0.15 & 0.48 & HP log ur t-7 & $-0.82^{* * *}$ & 0.2 & 0.52 & HP log ur $<0 \mathrm{t}-7$ & $-0.61^{* *}$ & 0.27 & 0.62 \\
\hline Log ir $t-1$ & $-0.58^{* * *}$ & 0.12 & & Log ir $t-1$ & $-0.78^{\star * *}$ & 0.11 & & Log ir $t-1$ & $-0.56^{* * *}$ & 0.15 & \\
\hline Log ur t-8 & $-0.30^{* *}$ & 0.15 & 0.48 & HP log ur t-8 & $-1.10^{* * *}$ & 0.19 & 0.55 & HP log ur $<0$ t-8 & $-0.86^{* * *}$ & 0.25 & 0.65 \\
\hline Log ir $t-1$ & $-0.66^{* * *}$ & 0.12 & & Log ir $t-1$ & $-0.80^{* * *}$ & 0.11 & & Log ir $t-1$ & $-0.61^{* * *}$ & 0.14 & \\
\hline Log ur t-9 & $-0.50^{* * *}$ & 0.15 & 0.49 & HP log ur t-9 & $-1.13^{* * *}$ & 0.18 & 0.56 & HP log ur $<0$ t-9 & $-1.03^{* * *}$ & 0.25 & 0.66 \\
\hline Log ir $t-1$ & $-0.73^{* * *}$ & 0.11 & & Log ir $t-1$ & $-0.78^{\star \star \star}$ & 0.10 & & Log ir $t-1$ & $-0.63^{* * *}$ & 0.14 & \\
\hline Log ur $\mathrm{t}-10$ & $-0.63^{* * *}$ & 0.14 & 0.51 & HP log ur $t-10$ & $-1.16^{\star * \star}$ & 0.18 & 0.57 & HP log ur $<0$ t-10 & $-1.23^{* * *}$ & 0.24 & 0.7 \\
\hline Log ir t-1 & $-0.72^{* * *}$ & 0.11 & & Log ir t-1 & $-0.72^{* * *}$ & 0.10 & & Log ir t-1 & $-0.66^{* * *}$ & 0.13 & \\
\hline
\end{tabular}

Notes: Quarterly fixed effects estimation with seasonal dummy variables; regions North, South, East, West; T=49 (Q1 1997 - Q1 2009 ); *** **, *: statistically significant at $1 \%, 5 \%, 10 \%$, respectively ;seasonal dummy variables are always jointly significant at the one percent level; coefficients from individual estimations (not jointly estimated); number of observations in third regression $=96$. 
Table 8: The effect of unemployment and GDP on business registrations with controls

\begin{tabular}{|c|c|c|c|c|}
\hline \multicolumn{5}{|c|}{ Dependent Variable: Log business registrations } \\
\hline & I & II & III & IV \\
\hline Log unemployment rate $\mathrm{t}-1$ & $\begin{array}{l}0.42^{* *} \\
(0.14)\end{array}$ & & & \\
\hline HP log unemployment rate $\mathrm{t}-1$ & & $\begin{array}{c}0.79^{* * *} \\
(0.27)\end{array}$ & & \\
\hline Real GDP growth $\mathrm{t}-1$ & & & $\begin{array}{l}-1.16 \\
(1.09)\end{array}$ & \\
\hline HP log real GDP t-1 & & & & $\begin{array}{c}-5.19^{* * *} \\
(1.47)\end{array}$ \\
\hline Log difference patent intensity & $\begin{array}{l}0.31^{*} \\
(0.18)\end{array}$ & $\begin{array}{c}0.29 \\
(0.18)\end{array}$ & $\begin{array}{l}0.31^{*} \\
(0.19)\end{array}$ & $\begin{array}{l}0.32^{*} \\
(0.18)\end{array}$ \\
\hline Log self-employment rate & & & $\begin{array}{l}0.15^{\star *} \\
(0.07)\end{array}$ & \\
\hline Constant & $\begin{array}{c}-4.2^{* * *} \\
(0.31)\end{array}$ & $\begin{array}{c}-5.10^{* * *} \\
(0.03)\end{array}$ & $\begin{array}{c}-4.7^{\star * *} \\
(0.19)\end{array}$ & $\begin{array}{c}-5.11^{* * *} \\
(0.03)\end{array}$ \\
\hline Breakdummy & $\begin{array}{c}1.0 \\
(0.04)^{\star \star \star} \\
(0.04)\end{array}$ & $\begin{array}{c}0.97^{* * *} \\
(0.04)\end{array}$ & $\begin{array}{c}0.94^{* * *} \\
(0.04)\end{array}$ & $\begin{array}{c}0.98^{* * *} \\
(0.04)\end{array}$ \\
\hline R2 within & 0.79 & 0.79 & 0.79 & 0.80 \\
\hline
\end{tabular}

Notes: Fixed effects estimations with 192 observations. ${ }^{* * *},{ }^{* *},{ }^{*}$ : statistically significant at $1 \%, 5 \%, 10 \%$, respectively; standard errors in parentheses. 


\section{Appendix}

Table A1: Definition of Variables and data sources

\begin{tabular}{|c|c|c|}
\hline Variable & Definition & Data source \\
\hline $\begin{array}{l}\text { Rate of } \\
\text { business } \\
\text { registrations }\end{array}$ & $\begin{array}{l}\text { Number of new business registrations } \\
\text { over civil labor force }\end{array}$ & Business Registration Statistics \\
\hline $\begin{array}{l}\text { New business } \\
\text { formation rate }\end{array}$ & $\begin{array}{l}\text { Number of new businesses } \\
\text { (extrapolated to the entire population) } \\
\text { over civil labor force }\end{array}$ & Micro-Census \\
\hline $\begin{array}{l}\text { Self- } \\
\text { employment } \\
\text { rate }\end{array}$ & $\begin{array}{l}\text { Number of self-employed persons (first } \\
\text { employment) over civil labor force }\end{array}$ & $\begin{array}{l}\text { Federal Statistical Office, } \\
\text { Working Committee } \\
\text { "Volkswirtschaftliche } \\
\text { Gesamtrechnung der Länder" }\end{array}$ \\
\hline $\begin{array}{l}\text { Patent } \\
\text { intensity }\end{array}$ & $\begin{array}{l}\text { Number of patent applications over civil } \\
\text { labor force }\end{array}$ & Federal Statistical Office \\
\hline $\begin{array}{l}\text { Unemployment } \\
\text { rate }\end{array}$ & $\begin{array}{l}\text { Number of registered unemployed } \\
\text { persons over the entire working } \\
\text { population }\end{array}$ & Federal Employment Agency \\
\hline $\begin{array}{l}\text { Real Gross } \\
\text { Domestic } \\
\text { Product }\end{array}$ & $\begin{array}{l}\text { Nominal GDP divided by the annual } \\
\text { consumer price index (CPI) of the } \\
\text { Federal Statistical Office }\end{array}$ & $\begin{array}{l}\text { Federal Statistical Office, } \\
\text { Working Committee } \\
\text { "Volkswirtschaftliche } \\
\text { Gesamtrechnung der Länder" }\end{array}$ \\
\hline Interest rate & $\begin{array}{l}\text { Lending rates of banks, long-term fixed- } \\
\text { rate loans to enterprises and self- } \\
\text { employed persons, EUR } 100,000 \text { and } \\
\text { more but less than EUR 500,000, } \\
\text { effective interest rate, available until } \\
2003 \text {; from } 2003 \text { on linked to effective } \\
\text { interest rates of German banks, loans to } \\
\text { non-financial corporations with a } \\
\text { maturity of over } 5 \text { years }\end{array}$ & Deutsche Bundesbank \\
\hline
\end{tabular}

